\title{
The Policy Design to Assistance Tech Startup for Reducing the Impact of Covid-19 Pandemic
}

\author{
Teguh Dwi Cahyanto ${ }^{1}$, Intan Satwika Putri², Moh Hamdani ${ }^{3}$ \\ \{teguh.dwi@bppt.go.id ${ }^{1}$,intan.satwika@bppt.go.id ${ }^{2}$, moh.hamdani@bppt.go.id ${ }^{3}$ \}
}

Balai inkubator teknologi, inkubator teknologi BPPT building ${ }^{1}$, Balai inkubator teknologi, inkubator teknologi BPPT building ${ }^{2}$, Balai inkubator teknologi, inkubator teknologi BPPT building ${ }^{3}$

\begin{abstract}
In 2020, The Covid-19 pandemic, have a significant impact for economics and also for Start-Up Technology (PPBT) in Indonesia. because PPBT also receives a disruptive impact on their business stability. This research aims to develop a policy design to assistance PPBT for reducing the impact of covid-19 pandemic which is expected to help incubators to assist PPBT who are being fostered. The method used in this research consists of: (1) Analysis of the general conditions of the problems being experienced by PPBT during the Covid-19 Pandemic; (2) Analysis of Policy Design to Assistance PPBT, using analysis of internal factors and external factors, SWOT matrix and AHP. Alternative of policy design obtained from this research consists of: (1) Facilitating the development of products and markets for innovative product in health and medicine, agriculture and food security, and information technology, by utilize business network and good distribution and electronic transaction system; (2) Strengthening coordination of incubators and related institutions to branding PPBT product as a local supplier with B2B and B2G system; (3) Facilitating the development business model of PPBT affected covid-19 pandemic to improve their business by adjusting market conditions; (4) Strengthening the incubator coordination for funding access as an effort to maintain the existence of PPBT.
\end{abstract}

Keywords: The Covid-19 Pandemic, Start-Up Technology, Policy Design

\section{Introduction}

2020 is the most difficult year for Indonesia and the whole world. Growth in the economic sector was severely affected and weakened as a result of the Covid-19 pandemic. Based on data from Central Bureau of Statistics, economic growth in Indonesia in the second quarter of 2020 compared to the second quarter of 2019 there was a growth contraction of 5.32\% [1]. The slowing down of economic growth is an indication of the negative impact on the Indonesian economy caused by the Covid-19 pandemic. The implementation of this policy has had an impact on many sectors and even more so on tech startups in Indonesia. Tech startups in this study are defined as new enterprises that graduated from the business incubation process. 
This study aims to formulate a tech startup mentoring policy design to reduce the impact of the Covid-19 pandemic which is expected to help business incubators during the pandemic. In addition, this research is also expected to support the development of tech startups both when the Covid-19 pandemic is still ongoing and after the covid-19 pandemic. The formulation of policy compiled in this study is expected to be the basis for stakeholders, especially for policy makers in making decisions for policies that support tech startups so that later they can support economic growth in Indonesia.

\section{Methodology}

The study consisted of two stages namely:

1). Initial Data Collection Stage

In this initial data collection phase, the aim is to find out the general condition of technology startups during a pandemic. The primary data collection methodology that used was a questionnaire and then analyzed with descriptive statistics. The questions given to tech starups are how the impact of the covid-19 pandemic on company sales, labor conditions, product innovation related to the covid-19 pandemic, and business barriers.

The respondents of initial data collection were: (1) technology startups graduated from the Technology Based Incubation Center Agency for the Assessment and Application of Technology (BITBPPT), (2) technology startups that receive incubation incentives from the Ministry of Research and Technology / National Research dan Innovation Agency, (3) and also a technology startup under the incubator business member of the Indonesian Business Incubator Association (AIBI). The technological scope of the technology startups that were respondents: energy, Information Technology, health and medicine, manufacturing, transportation, and agriculture and food resiliance. 
2). Policy Design Analysis Phase to help technology startups reduce the impact of the COVID-19 pandemic

In the policy formulation phase, the methodology used was the analysis of internal and external factors, the SWOT matrix, and the Analytic Hierarchy Process (AHP).

Data from the experts was obtained directly from interviews and questionnaires (AHP questionnaire), then the FGD was conducted to formulate the policy design.

The experts and actors involved in the FGD are: (1) Head of the incubator, (2) CEO of tech startup, (3) Representatives from the Ministry, and (4) Supporters (Academics and investors). Secondary data used in this study came from various literary sources.

\subsection{Internal and External Factor Analysis}

Internal and external factors are obtained by analyzing: (1) internal environment in the form of strengths and weaknesses of technology startups and incubators during the Covid-19 pandemic, and (2) analysis of the external environment in the form of opportunities and threats faced both during the pandemic and post Covid-19 pandemic.

Internal strengths and weaknesses are activities that controlled by an organization that can give a very good or bad impact to the organization. Those internal strengths and weaknesses could be arise in management, marketing, finance / accounting, production / operations, research and development, and business management information system activities. Analysis of the external environment could be used to summarize and evaluate opportunities and threats from economic, social, cultural, demographic, environmental, political, governance, legal, technological, and competitive or competitive information [4].

\subsection{Analysis of Strengths, Weaknesses, Opportunities and Threats}

Strength, Weakness, Opportunity and Threat (SWOT) analysis is a tool that can be used to determine the conditions or problems experienced by technology startups, incubator agencies, and other stakeholders caused by a pandemic outbreak 19. SWOT analysis can also be used to find policy designs which can be used to help reduce this impact. According to Eriyatno and Larasati (2013) [5], Another function of the SWOT analysis is that it can be 
used to show a framework that can help planners to identify strategies to achieve goals. In a SWOT analysis a combination of four types of strategies can be carried out, namely: SO strategy, WO strategy, ST strategy and WT strategy. The SWOT matrix is derived from the input stage to match or combine internal strengths and weaknesses with external opportunities and threats. The analysis results can be displayed in the SWOT matrix.

The SWOT matrix can clearly illustrate how external opportunities and threats from the impact of the Covid-19 pandemic outbreak can be adjusted to the strengths and weaknesses identified from PPBT and the incubator conditions in business, company turnover, labor, legality, etc.

According to Rangkuti (2014) [8], the steps in preparing a SWOT matrix are as follows:

1) Makes 5 to 10 internal strengths owned and reserved for Strength cells.

2) Makes 5 to 10 internal weaknesses that are owned and attached to weak cells.

3) Create 5 to 10 Opportunities lists.

4) Make 5 to 10 lists of external threats that are approved and stored in the Threat cell.

5) Make alternative policies based on a combination of 4 strategic regulatory factors such as the assessment in Table 1.

Table 1. SWOT Matrix (Rangkuti, 2014) [8]

\begin{tabular}{|c|c|c|}
\hline Internal & Strengths (S) & Weaknesses (W) \\
\hline Opportunities (O) & $\begin{array}{l}\text { SO Strategy } \\
\text { This strategy is made by using all } \\
\text { power to take advantage of } \\
\text { opportunities. }\end{array}$ & $\begin{array}{l}\text { WO Strategy } \\
\text { This is a strategy created by exploiting } \\
\text { opportunities to overcome weaknesses. }\end{array}$ \\
\hline Threats (T) & $\begin{array}{l}\text { ST Strategy } \\
\text { This strategy is made by using all } \\
\text { power to overcome threats. }\end{array}$ & $\begin{array}{l}\text { WT Strategy } \\
\text { This strategy is a defense strategy that } \\
\text { is made by minimizing existing } \\
\text { weaknesses and avoiding threats. }\end{array}$ \\
\hline
\end{tabular}

\subsection{Analytical Hierarchy Process}

Analytical Hierarchy Process (AHP) was chosen because it can be used for decision making to determine priorities for policy alternatives, in this study 
it is used to prioritize policy alternatives for mentoring startups affected by the Covid-19 pandemic. The approach of the AHP is problem solving of a hierarchical structure and are interrelated. AHP was developed by Dr. Thomas L. Saaty to organize information in choosing the most preferred alternative.

The AHP method is used to simplify complex problems that are more structured and easy to solve. AHP method can be used to choose policy alternatives that have been formulated through the SWOT matrix in the previous stage, policy alternatives will be chosen based on the priority scale (weight) generated from the AHP analysis [11]. This stage is the stage of determining the policy strategy (decision stage).

According to Eriyatno and Larasati (2013) [5], the AHP model uses human perception which is considered an expert as its main input. AHP is widely used for multi-criteria decision making tools, unlike conventional methods, AHP uses pairwise comparisons which allows for verbal judgment and improves the precision of the results.

Measurement of qualitative matters is very important because the more complex the problem, the higher the level of uncertainty. In addition, AHP also tests the consistency of the assessment, if there are deviations that are too far from the consistent value, the assessment made by an expert needs to be improved or the hierarchy must be restructured.

According to Syaifullah (2010) [9], AHP is often used as a method of solving problems compared to other methods for the following reasons:

a. The hierarchical structure, as a consequence of the chosen criteria, reaches the deepest sub-criteria.

b. Consider the validity of the various criteria and alternatives chosen by decision makers to the degree of inconsistency

c. Consider the resilience of the results of the sensitivity analysis in decision making

According to Marimin (2008) [6], there are four (4) basic ideas of AHP work principles as follows:

1) Hierarchical arrangement

The problem that need to be solved is break down into its elements such as targets, criteria and alternatives, then arranged into a hierarchical structure.

2) Assessment the criteria and alternatives 
Criteria and alternatives are assessed through a pairwise comparison matrix. With a scale of values and definitions of qualitative opinions between a scale of 1 to 9 . The scale is determined as a consideration in comparing pairs of elements at each level of the hierarchy against one element at the top level [9]. The values and definitions of qualitative opinions from the Saaty comparison scale can be seen in Table 2.

Table 2. Saaty comparison scale

\begin{tabular}{cl}
\hline Score & \multicolumn{1}{c}{ Information } \\
\hline $\mathbf{1}$ & Criteria / Alternative A is as important as criterion / alternative B \\
\hline $\mathbf{3}$ & A is slightly more important than B \\
\hline $\mathbf{5}$ & A is clearly more important than B \\
\hline $\mathbf{7}$ & A is clearly more important than B \\
\hline $\mathbf{9}$ & A Absolute is more important than B \\
\hline $\mathbf{2 , 4 , 6 , 8}$ & The value between two value considerations that are close together \\
\hline
\end{tabular}

The value of the comparison of $A$ with $B$ is 1 (one) divided by the value of the comparison of B with A.

3) Determination of Opportunities

Criteria and alternatives that have been compared in a pairwise comparison matrix are then processed to determine the relative ranking of all alternatives. Both qualitative and quantitative criteria can be compared according to predetermined assessments to produce weights and priorities. Weights or priorities are calculated by matrix manipulation or solving with mathematical equations.

4) Logical Consistency

All elements are logically grouped and ranked consistently according to logical criteria. Problems that have high consistency are needed for basic decision making so that the decision results become more accurate.

AHP problem solving methods used to determine alternative priorities for this policy use Super Decisions software that can display results that are more graphically attractive and easily understood. AHP method calculation with the help of decision support system applications will be faster than manual calculations so that it can be more efficient and the level of data accuracy is near perfect [3].

The use of Super Decisions Software starts with compiling a hierarchy of existing problems, then determining the value of pairwise comparisons between criteria and alternatives that exist in accordance with the AHP questionnaire that has been filled out by experts. In analysis with AHP, CR (Concistency Ratio) is 
used as a basis for knowing the consistency of the questionnaire content from experts, the consistency value should not be more than 0.10 [6].

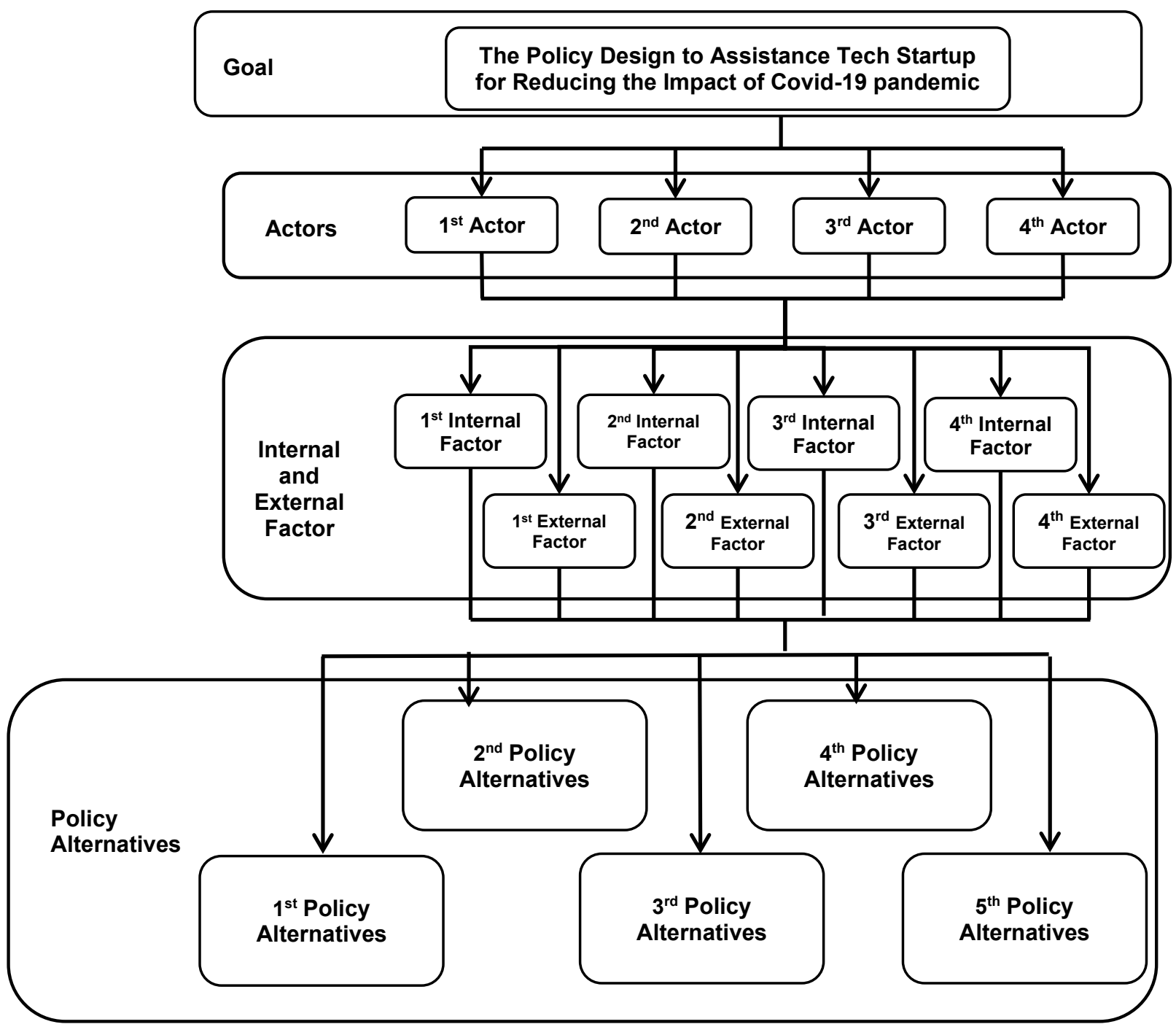

Fig. 1. The hierarchy of determining tech startups assistance policies for reducing the impact of Covid-19 pandemic. 


\section{Result and Discussion}

\section{Identification of Internal and External Factors}

Based on the results of the identification and analysis of internal and external factors of tech startups and incubators during the Covid-19 pandemic in the form of Strengths, Weakness, Opportunities and Threats that influence technology startup assistance, the results obtained can be used to determine policy design priorities in the SWOT analysis. Analysis of strengths, weaknesses, opportunities and threats of tech startups and incubators during the Covid-19 pandemic can be found in the SWOT profile as in table 3.

Table 3. SWOT Profile

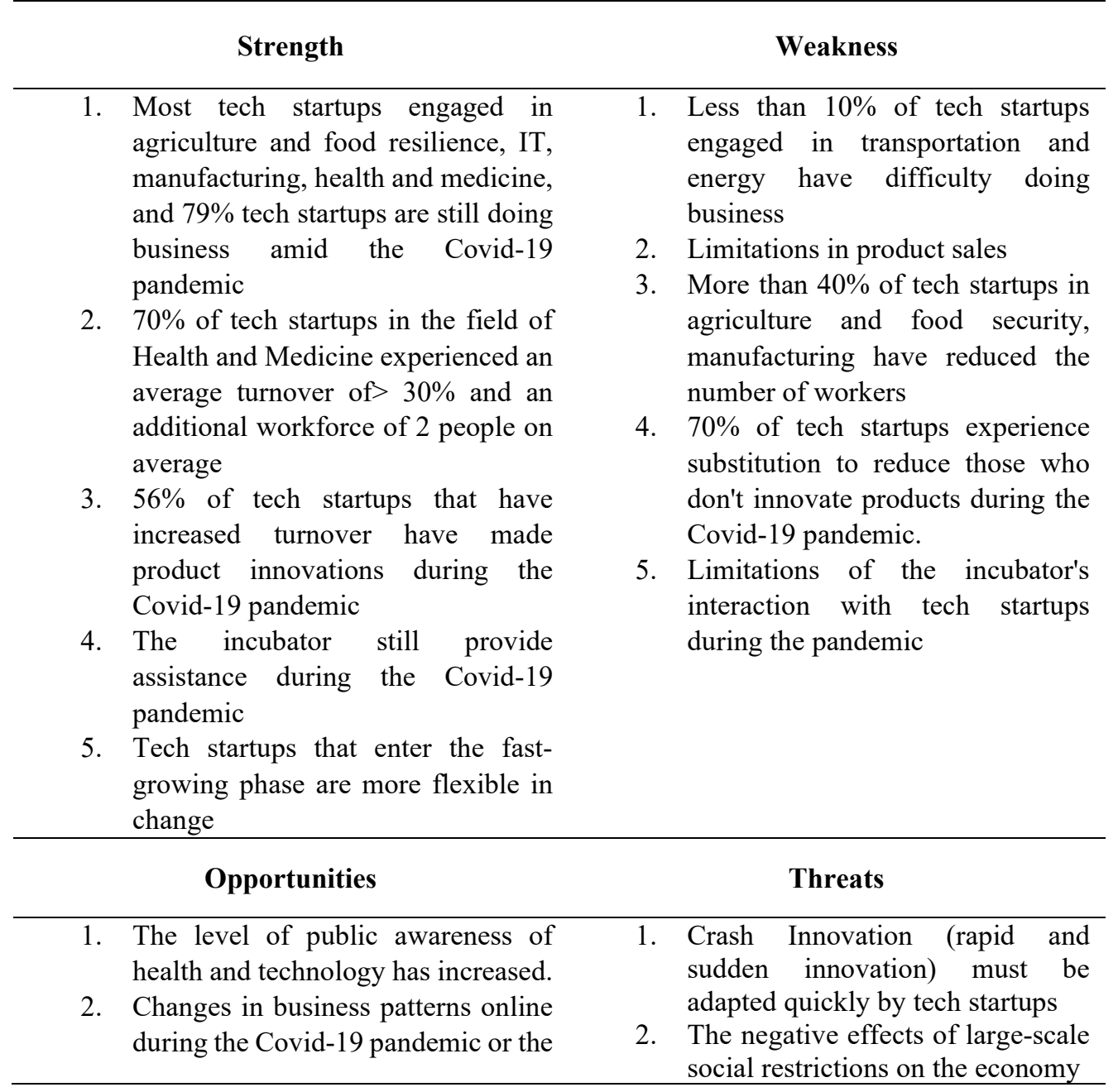


use of electronic transaction systems.

3. The direction of $\mathrm{B} 2 \mathrm{~B}$ or $\mathrm{B} 2 \mathrm{G}$ business is more promising than retail business

4. The effects of deglobalization after the pandemic, protocols in and out of the country increasingly stringent. Strengthening of domestic suppliers.

5. Predictions of Indonesia's economic growth remain positive.

6. Incubator institutional certification and incubator's facilitators / HR expertise certification
3. An increase in the number of layoffs, a reduction in the level of public and government consumption and GDP

4. Decreasing the level of consumption of the people and government

5. The reduced level of investment

6. Limited qualifications of incubator's facilitators/human resources

\subsection{SWOT Matrix Analysis}

After identifying the internal and external factors of tech startups and incubators, the next step is the stage of combining Strengths, Weaknesses, Opportunities and Threats using the SWOT matrix. The results of the formulation are grouped into 4 (four) strategy formulation groups consisting of the Strength-Opportunity (SO) strategy, Weakness-Opportunity (WO) strategy, Strength-Threat (ST) strategy, and Weakness-Threat (WT) strategy, as presented in Table 4. 


\begin{tabular}{|c|c|c|}
\hline External Factor & $\begin{array}{l}\text { (S) } \\
\text { 1. Most tech startups engaged in agriculture and food } \\
\text { resilience, IT, manufacturing, health and medicine, and } \\
79 \% \text { tech startups are still doing business amid the } \\
\text { Covid-19 pandemic } \\
\text { 2. } 70 \% \text { of tech startups in the field of Health and Medicine } \\
\text { experienced an average turnover of }>30 \% \text { and an } \\
\text { additional workforce of } 2 \text { people on average } \\
\text { 3. } 56 \% \text { of technology startups that have increased turnover } \\
\text { have made product innovations during the Covid-19 } \\
\text { pandemic } \\
\text { 4. The incubator still provide assistance during the Covid- } \\
19 \text { pandemic } \\
\text { 5. Tech startups that enter the fast-growing phase are more } \\
\text { flexible in change }\end{array}$ & $\begin{array}{l}\text { (W) } \\
\text { 1. Less than } 10 \% \text { of tech startups engaged in } \\
\text { transportation and energy have difficulty doing } \\
\text { business } \\
\text { 2. Limitations in product sales } \\
\text { 3. More than } 40 \% \text { of tech startups in agriculture and } \\
\text { food security, manufacturing have reduced the } \\
\text { number of workers } \\
\text { 4. } 70 \% \text { of tech start-ups experience substitution to } \\
\text { reduce those who don't innovate products during } \\
\text { the Covid-19 pandemic. } \\
\text { 5. Limitations of the incubator's interaction with tech } \\
\text { startups during the pandemic } \\
\text { 6. Limited qualifications of incubator's } \\
\text { facilitators }\end{array}$ \\
\hline $\begin{array}{l}\text { (O) } \\
\text { 1. The level of public awareness of health and } \\
\text { technology has increased. } \\
\text { 2. Changes in business patterns online during } \\
\text { the Covid-19 pandemic or the use of } \\
\text { electronic transaction systems. } \\
\text { 3. The direction of B2B or B2G business is } \\
\text { more promising than retail business } \\
\text { 4. The effects of deglobalization after the } \\
\text { pandemic, protocols in and out of the country } \\
\text { increasingly stringent. Strengthening of } \\
\text { domestic suppliers. } \\
\text { 5. Predictions of Indonesia's economic growth } \\
\text { remain positive. }\end{array}$ & $\begin{array}{l}\text { SO Strategy } \\
\text { 1. Facilitating product and market development by } \\
\text { utilizing business networks and distribution through } \\
\text { electronic transaction systems in the fields of health and } \\
\text { medicine, agriculture and food resilience, and IT (S1, } \\
\text { S2, S3, S4, S5, O1, O2, O3) } \\
\text { 2. Strengthening coordination of incubators and related } \\
\text { institutions to encourage tech startups products as local } \\
\text { suppliers to B2B and B2G systems (S3, S4, S5, O4, O5) }\end{array}$ & $\begin{array}{l}\text { WO Strategy } \\
\text { 1. Strengthening the incubator and its HR through } \\
\text { institutional certification and professional certification } \\
\text { for facilitators assigned as tech startups assistants (W5, } \\
\text { W6, O1, O2, O3, O4, O5, O6) }\end{array}$ \\
\hline
\end{tabular}




\begin{tabular}{|c|c|c|c|}
\hline 6. & $\begin{array}{l}\text { Incubator institutional certification and } \\
\text { incubator's facilitators / HR expertise } \\
\text { certification. }\end{array}$ & & \\
\hline & $\begin{array}{l}\text { (T) } \\
\text { Crash Innovation (rapid and sudden } \\
\text { innovation) must be adapted quickly by tech } \\
\text { startups } \\
\text { The negative effects of large-scale social } \\
\text { restrictions on the economy } \\
\text { An increase in the number of layoffs, a } \\
\text { reduction in the level of public and } \\
\text { government consumption and GDP } \\
\text { Decreasing the level of consumption of the } \\
\text { people and government } \\
\text { The reduced level of investment } \\
\text { Limited qualifications of incubator's } \\
\text { facilitators/Human Resources }\end{array}$ & $\begin{array}{l}\text { ST Strategy } \\
\text { 1. Facilitating the development of tech startups business } \\
\text { models to be flexible to crash innovation in accordance } \\
\text { with conditions due to the Large-Scale Social } \\
\text { Limitation policy (S3, S4, S5, T1, T2, T3, T4, T5) } \\
\text { 2. Strengthening the coordination of incubators and } \\
\text { related institutions in suppressing market prices to } \\
\text { maintain the level of public consumption (S4, S5, T3, } \\
\text { T4, T5) } \\
\text { 3. Facilitating the development of tech startups business } \\
\text { models for business improvement by adjusting market } \\
\text { conditions/needs (S1, S2, S3, S4, S5, T2, T3, T4) }\end{array}$ & $\begin{array}{l}\text { WT Strategy } \\
\text { 1. Strengthening incubator coordination with capital } \\
\text { institutions as an effort to maintain the existence of } \\
\text { technology startups (W3, W4, W5, T4, T5) }\end{array}$ \\
\hline
\end{tabular}




\subsection{Policy Formulation using AHP Method}

Policy alternatives that have been formulated through the SWOT matrix, are then processed by the AHP method through the Super Decisions software based on a questionnaire that has been filled out by experts. The determination of policy priorities is a combination of opinions from experts represented by incubators, technology startups, governments, academics, and investors.

\subsection{The selection of actors who play a role in determining policy}

With the assessment and merging of the opinions of the experts with the aim as the basis for determining the tech startups assistance policy for reducing the impact of Covid-19 pandemic, the priority results are obtained as shown in table 5 .

Table 5. Actors who play a role in determining policy

\begin{tabular}{lcc}
\hline \multicolumn{1}{c}{ Actor } & Weight & Priority \\
\hline Head of the incubator, & 0,37736 & 1 \\
\hline CEO of a tech startup, & 0,29683 & 2 \\
\hline Government.Supporters, & 0,22536 & 3 \\
\hline (Academics and investors) & 0,10045 & 4 \\
\hline
\end{tabular}




\subsubsection{Selection of Factors that Influence Policy Decisions}

The chosen factors in determining the tech startups' assistance policy for reducing the impact of Covid-19 pandemic are internal and external environmental factors of tech startups and incubators, as follows:

1. Product innovation

2. Increased revenue in the field of health technology and medicine

3. Limitations in product sales

4. Reduction in the number of workers

5. Changes of business models

6. Stricter import protocols

7. Negative effects of applying LSSR (Large-scale Social Limitation) on the economy

8. Decrease in the level of investment

With the assessment and merging of opinions of experts based on the actors who play a role in determining policy, the priority results are obtained as shown in table 6.

Table 6. Factors that influence in determining policy

\begin{tabular}{lcc}
\hline \multicolumn{1}{c}{ Internal and External Factors } & Weight & Priority \\
\hline Changes of business models & 0,17073 & 1 \\
\hline Product innovation & 0,15700 & 2 \\
\hline $\begin{array}{l}\text { Increased revenue in the field of health technology and } \\
\text { medicine }\end{array}$ & 0,14777 & 3 \\
\hline Decrease in the level of investment & 0,11625 & 4 \\
\hline Stricter import protocols & 0,11209 & 5 \\
\hline Limitations in product sales & 0,10343 & 6 \\
\hline Reduction in the number of workers & 0,09741 & 7 \\
\hline $\begin{array}{l}\text { Negative effects of applying LSSR (Large-scale Social } \\
\text { Limitation) on the economy }\end{array}$ & 0,09531 & 8 \\
\hline
\end{tabular}




\subsubsection{Formulation of alternative policies}

The formulation of alternative policies for tech startups assistance in order to reduce the impact of Covid-19 pandemic based on the policy formulation resulting from the SWOT matrix selected and assessed according to and representing each of the SO, ST, WO and WT strategies, as follows:

1. Facilitating product and market development by utilizing business and distribution networks through electronic transaction systems in the fields of health and medicine, agriculture and food resilience, and IT

2. Strengthening the coordination of incubators and related institutions to encourage tech startups products as local suppliers to B2B and B2G systems.

3. Facilitating the development of tech startups business models for business improvement by adjusting market conditions and needs.

4. Strengthening the coordination of incubators with capital institutions as an effort to maintain the existence of tech startups.

5. Strengthening the incubator and human resources assigned as a companion through institutional certification and professional certification of facilitators as tech startups companion.

Based on the results of the analysis by the AHP method and based on the merging of the opinions of experts and based on the principle of pairwise comparisons, the results obtained are priorities for alternative tech startups assistance for reducing the impact of Covid-19 pandemic as shown in Table 7.

Table 7. Policy alternatives

\begin{tabular}{lcc}
\hline \multicolumn{1}{c}{ Policy Alternatives } & Weight & Priority \\
\hline $\begin{array}{l}\text { Facilitating the development of tech startups business models } \\
\text { for business improvement by adjusting market conditions and } \\
\text { needs. }\end{array}$ & & 1 \\
\hline $\begin{array}{l}\text { Facilitating product and market development by utilizing } \\
\text { business and distribution networks through electronic }\end{array}$ & & \\
transaction systems in the fields of health and medicine, & & \\
agriculture and food resilience, and IT & & \\
\hline $\begin{array}{l}\text { Strengthening the coordination of incubators and related } \\
\text { institutions to encourage tech startups products as local } \\
\text { suppliers to B2B and B2G systems. }\end{array}$ & & \\
\hline
\end{tabular}




\begin{tabular}{l} 
Strengthening the coordination of incubators with capital 0,16925 \\
institutions as an effort to maintain the existence of tech \\
startups. \\
\hline $\begin{array}{l}\text { Strengthening the incubator and human resources assigned as } 0,09859 \\
\text { a companion through institutional certification and }\end{array}$ \\
professional certification of facilitators as tech startups \\
companion.
\end{tabular}

The results of the analysis of policy priorities using the AHP method showed the weight priorities and the most important policy priorities that must be carried out by incubators and stakeholders, presented in Figure 2 . The results obtained from setting priorities using the AHP method are quite relevant to the conditions of technology startups and incubators in the Covid-19 pandemic. 


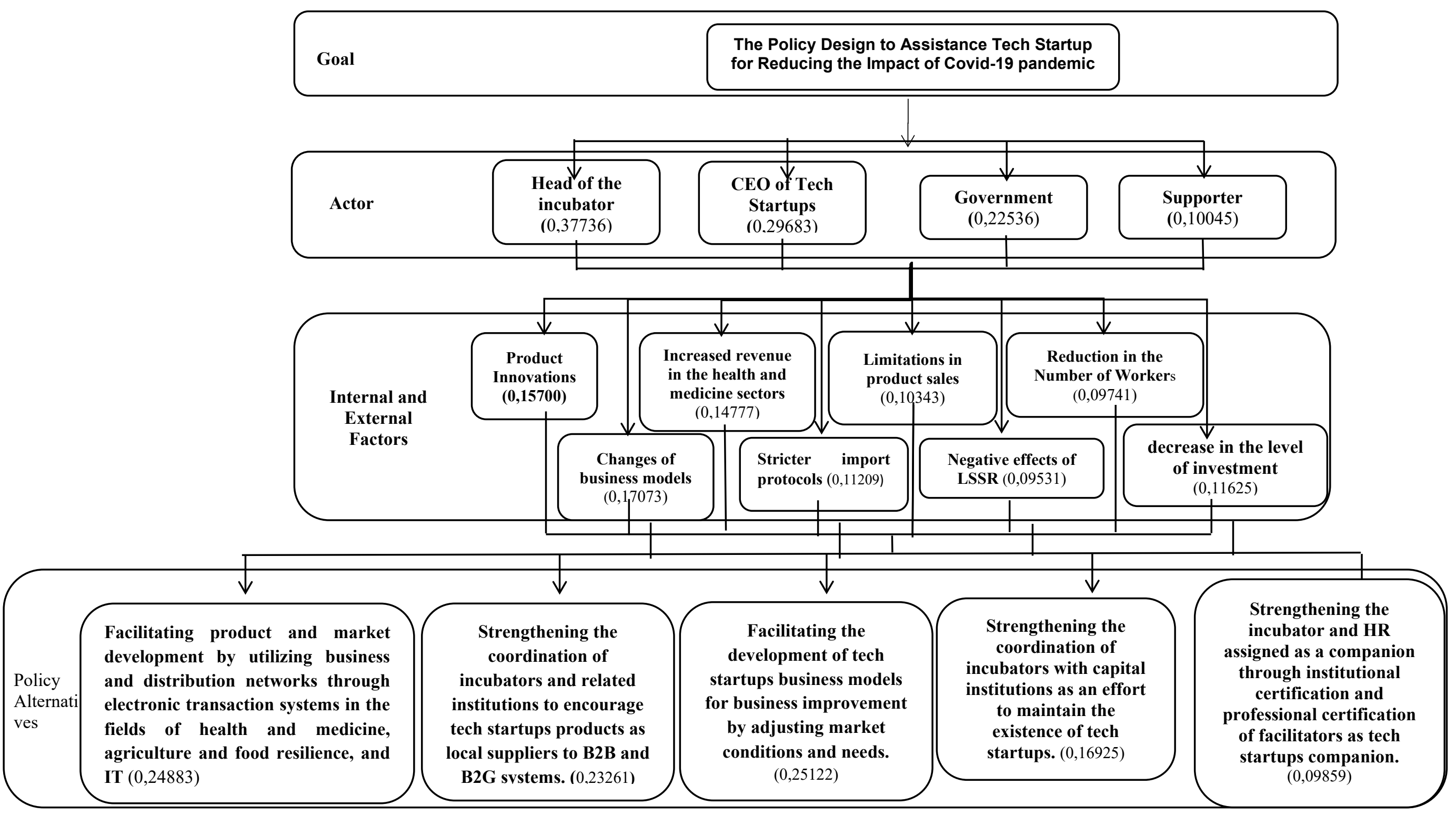

Fig. 2. Weight of alternative policies with the AHP method 


\section{Conclusion}

Based on the analysis of internal and external factors of tech startups and incubators, internal factors that are the main strengths are Product innovation while the main weakness is Limitations in product sales. For external factors it is the biggest opportunity is Changes of business models, while the biggest threat is Decrease in the level of investment.

Based on the results of the analysis using the AHP method, alternative assistance policies for tech startups to reduce the impact of Covid-19 pandemic, the priority order is as follows: (1) Facilitating the development of tech startups business models for business improvement by adjusting market conditions and needs, (2) Facilitating product and market development by utilizing business and distribution networks through electronic transaction systems in the fields of health and medicine, agriculture and food resilience, and Iinformation Technology, (3) Strengthening the coordination of incubators and related institutions to encourage tech startups products as local suppliers to B2B and B2G systems, (4) Strengthening the coordination of incubators with capital institutions as an effort to maintain the existence of tech startups, (5) Strengthening the incubator and human resources assigned as a companion through institutional certification and professional certification of facilitators as tech startups companion.

\section{Acknowledgments}

The authors would like to express the deepest gratitude to those who have helped complete the tech startups advisory policy design research for reducing the impact of Covid-19 pandemic. Hopefully this article is useful as a basis for making decisions on the development of tech startups in Indonesia 


\section{References}

[1] [BPS] Berita Resmi Statistik Badan Pusat Statistik. 2020. Pertumbuhan Ekonomi Indonesia triwulan II-2020 No. 64/08/Th.XXIII, 5 Agustus 2020. http://bps.go.id [6 Agustus 2020].

[2] Cahyanto,T.D.(2016). Analisis Kelayakan dan Strategi Pengembangan Usaha pada Industri Minyak Atsiri di PT XYZ (Studi Kasus Tenant Balai Inkubator Teknologi). Tesis, Institut

[3] Darmanto E, Latifah N, Susanti N. 2014. Penerapan Metode AHP (Analythic Hierarchy Process) Untuk Menentukan Kualitas Gula Tumbu. Jurnal SIMETRIS. 5(1):75-82.

[4] David, Fred R. 2009. Manajemen Strategis Konsep. Sunardi D, penerjemah; Wuriarti P, editor. Jakarta: Salemba Empat. Terjemahan dari: Strategic Management. Ed ke-12.Eriyatno, Larasati L. 2013. Ilmu Sistem Meningkatkan Integrasi dan Koordinasi Manajemen, Jilid 2. Surabaya: Guna Widya.

[5] Eriyatno, Larasati L. 2013. Ilmu Sistem Meningkatkan Integrasi dan Koordinasi Manajemen. Guna Widya

[6] Marimin. 2008. Teknik dan Aplikasi Pengambilan Keputusan Kriteria Majemuk. Jakarta: PT Gramedia Widiasarana Indonesia.

[7] Ommani AR. 2011. Strengths, Weaknesses, Opportunities and Threats (SWOT) Analysis for Farming System Businesses Management: Case of Wheat Farmers of Shadervan District, S houstar Township, Iran. African Journal of Business Management. 5(22):9448-9454.

[8] Rangkuti F. 2014. Analisis SWOT: Teknik Membedah Kasus Bisnis. Jakarta: PT Gramedia Pustaka Utama.

[9] Saaty TL. 1993. Pengambilan Keputusan Bagi Para Pemimpin: Proses Hirarki Analitik untuk Pengambilan Keputusan dalam Situasi yang Kompleks. Setiono L, penerjemah; Peniwati K, editor. Jakarta: PT Pustaka Binaman Pressindo. Terjemahan dari: Decision Making for Leaders: The Analytical Hierarchy Process for Decisions in Clompex World.

[10] Syaifullah. 2010. Pengenalan Metode AHP (Analytical Hierarchy Process) [internet] [diunduh 2020 Mei 5]. Tersedia pada: http://syaifullah08.files. wordpress.com/2010/02/pengenalan-analyticalhierarchy-process.pdf.

[11] Wicaksono DT. 2012. Kelayakan dan Strategi Pengembangan Usaha Pembibitan Sagu Oleh PT Y di Lokasi Perkebunan Sagu PT X [tesis]. Bogor (ID): Institut Pertanian Bogor. 